\title{
Comparison of Fatty Acid Composition and Antioxidant Contents of Tribulus Terrestris L. Collected from Different Localities
}

\author{
Nazan Çömlekçioğlu ${ }^{1, a, *}$, Rıdvan Çırak ${ }^{1, b}$ \\ ${ }^{1}$ Department of Biology, Faculty of Science and Letters, Kahramanmaraş Sütçü Imam University, 46000 Kahramanmaraş, Turkey \\ *Corresponding author
}

\begin{tabular}{|c|c|}
\hline A R T I C E I N F O & A B S T R A C T \\
\hline $\begin{array}{l}\text { Keywords: } \\
\text { Antioxidant activity } \\
\text { Fatty acids }\end{array}$ & $\begin{array}{l}\text { For a long time, many cultures around the world have used Tribulus terrestris L. in the prevention } \\
\text { and treatment of various diseases. In this study, the antioxidant activity and total phenolic and } \\
\text { flavonoid content of extracts obtained with various solvents from } T \text {. terrestris plant collected from } \\
\text { different localities in Kahramanmaraş were investigated. In addition, the fixed oil content of the } \\
\text { extracts was examined by GC-MS analysis and as a result, } 26 \text { different fatty acids were determined. } \\
\text { The main fatty acid components of plant extracts are linoleic acid, oleic acid and palmitic acid. The } \\
\text { total phenolic substance value of plant extracts varies between } 2.20-18-77 \mathrm{mg} \mathrm{g}^{-1} \text {, total flavonoid } \\
\text { amount varies between } 0.06-0.50 \mathrm{mg} \mathrm{g}^{-1} \text {, FRAP value varies between } 6.16-23.50 \mu \mathrm{g}^{-1} \text { and DPPH } \\
\text { value varies between } 1.54-10.54 \mu \mathrm{g} \mathrm{mL} \mathrm{mL}^{-1} \text {. It was observed that the solvents used in extraction affected } \\
\text { the bioactivity values rather than the locations. Although the absorbance values of the extracts } \\
\text { obtained with hexane were high, low extract yield affected the results. The highest values in all } \\
\text { characters examined were obtained from ethanolic extracts. }\end{array}$ \\
\hline
\end{tabular}

Fatty acids

Location

Solvent

Tribulus terrestris

Türk Tarım - Gıda Bilim ve Teknoloji Dergisi, 9(8): 1448-1454, 2021

\section{Farklı Lokalitelerden Toplanan Tribulus Terrestris L.'in Yağ Asidi Bileşimi ve Antioksidan İçeriklerinin Karşılaştırılması}

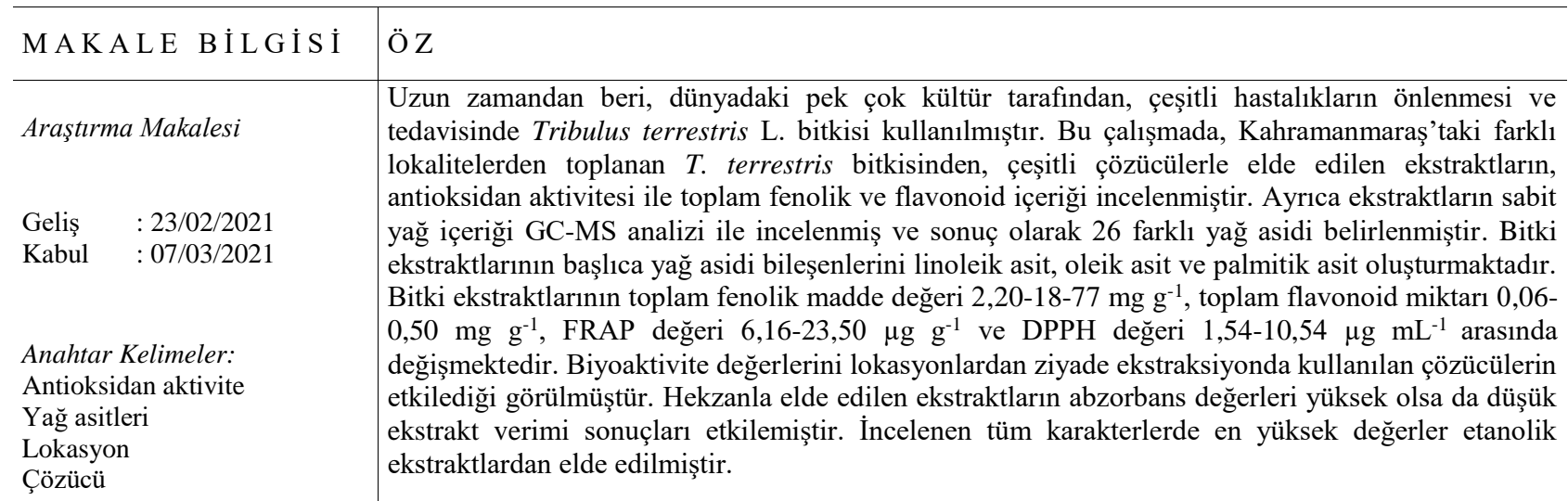

Tribulus terrestris 


\section{Introduction}

People have always suffered from infections caused by bacteria, fungi, viruses and parasites, as well as many ailments such as inflammation, colds, digestive problems, pain, and have applied natural and herbal remedies to treat these ailments (Wink, 2005; Sevindik et al., 2017; Mohammed et al., 2018). In the researches, it is estimated that $20.6 \%$ of the world population will be over 60 years old in 2050 (Cohen, 2001). These statistical estimates highlight the efforts to protect and improve the health of the ageing population. However, the failure and side effects of various chemotherapeutics available on the market have led global scientists and researchers to seek an alternative method to cure diseases and protect the health of the elderly population (Mohammed et al., 2020; Pandey and Gupta, 2020; Sevindik, 2020). The belief that frees radical reactions accelerate the ageing process means that interventions aimed at limiting or preventing them will decrease the rate of ageing and disease pathogenesis (Fusco et al., 2007; Sevindik, 2021). This has prompted research on the potential role of antioxidant plants in therapeutic or preventive strategies (Noordin et al., 2020). Bioactive secondary metabolites and phytochemicals from medicinal plants are expected to be more specific, biodegradable and have fewer side effects, so they can be a very good source for obtaining new and more effective drugs (Pandey and Gupta, 2020; Mohammed et al., 2019). Natural antioxidants and antimicrobials have many advantages over synthetic ones for human health and the environment (Tian et al., 2019-A). Plant-based antimicrobials are represented by a wide range of resources, and therefore continuous and further investigation of plant antimicrobials will lead to the discovery of new drugs. The main benefits of using plantderived medicines are that they are more affordable, offer effective therapeutic benefits, and are relatively safer than synthetic alternatives (Pandey and Gupta, 2020; Mohammed et al., 2021). As a result, compounds derived from these plants can be developed as health supplements or potential medicinal drugs in addition to maintaining the health of the ageing population (Noordin et al., 2020). For this reason, many plants that were previously collected from nature will need to be cultivated and grown in order to meet the demands of consumers. Tribulus terrestris L. also seems to be one of these plants (Pandey and Gupta, 2020).

T. terrestris, known as Gokshur (Sanskrit), Caltrops (English); Gokhru (in Hindi); and Khan-e-khusakkhurd (Urdu), Qutib to (Bedouin language) in several countries (Amin et al., 2006; Chhatre, 2014). In Turkey, T. terrestris named as Demirdikeni, Çarıkdikeni, Çobançökerten or Deveçökerten (Baytop, 1999). This herb, which is very common in our country, is used as infusion to treat stone reliever, diuretic and strengthener (Baytop, 1999). Tribulus is a genus of the Zygophyllaceae family. Tribulus has about 20 species in the world, but there are only $T$. terrestris species in Turkey. Over the past few decades, extensive research studies have been conducted to prove their biological activity and the pharmacology of its extracts. Anticancer (Kim et al., 2011), antimicrobial (Gopinath et al., 2012), antioxidant (Hammoda et al., 2013), analgesic and anti-inflammatory (Tian et al., 2019-B), antiurolitic, antidiabetic, cardiotonic (Amin et al., 2006), tonic, aphrodisiac, sexual enhancer (Akram et al., 2011), immunomodulator, absorption enhancer, hypolipidemic, antispasmodic (Chhatre, 2014) properties of T. terestris were investigated.
Although there are many pharmacology studies showing that $T$. terrestris functions well as an antioxidant and antimicrobial (Gopinath et al., 2012; Hammoda et al., 2013; Mohammed et al., 2014; Tian et al., 2019-A; Noordin et al., 2020), there are very few reports about fatty acids (Tian et al., 2019-B). Thus, the aim of this study is to investigate the content of beneficial bioactive compounds and antioxidant activities in $T$. terrestris plant. The total phenolic and flavonoid content, antioxidant activity of the plants collected from three different locations in Kahramanmaraş and the oil content of the extracts were investigated and the analysis of the fatty acid composition was performed in GC-MS.

\section{Material and Methods}

\section{Plant Material}

T. terrestris plant specimens used in this study were collected during the summer vegetation of 2019 from three different locations in Kahramanmaraş namely, Aksu in Onikişubat District, Ilıca in Dulkadiroğlu District and Kanlıkavak in Göksun District (Figure 1). The identification of the plant was made using Flora of Turkey and the East Aegean Islands Volume 2. (Davis, 1967).

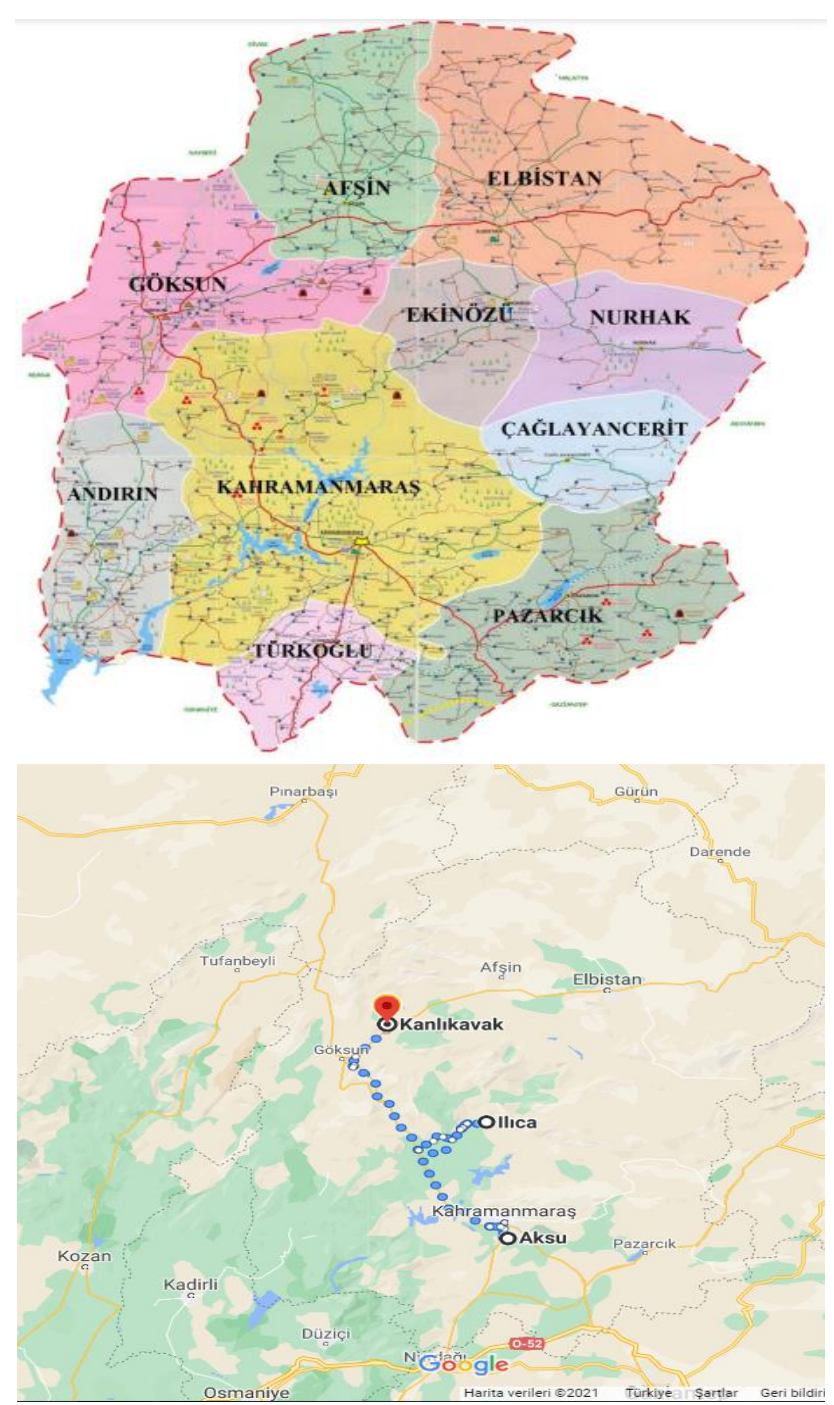

Figure 1. The presentation of the locations where the plants are collected on the map of Kahramanmaraş province 


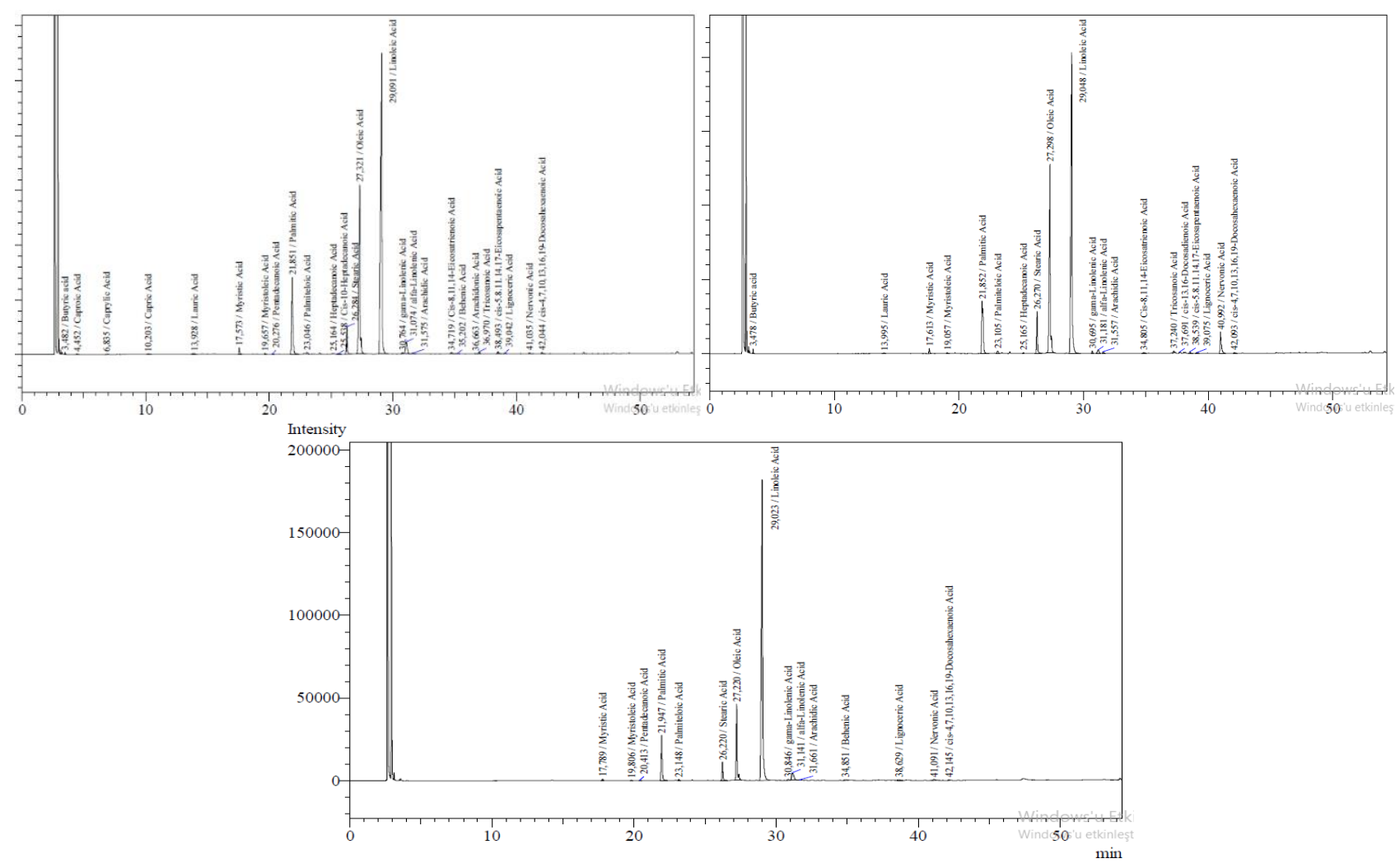

Figure 2. GC-MS chromatograms obtained from fruit extracts of T. terrestris.

(A: Aksu Location, B: Ilıca Location, C: Kanlıkavak Location)

\section{Sample Preparation}

After the plants were collected, they were dried at room temperature in a dry environment. The dried samples were ground in a laboratory grinder (Waring Commercial) and stored in glass bottles protected from light and moisture for use in the experiment.

\section{Extraction Method}

Polyphenols were extracted from $T$. terrestris plant samples with three different solvents: ethanol (Polarity index: 5.2), methanol (Polarity index: 6.6) and hexane (Polarity index: 0.0). The extraction method used was modified from Miliauskas et al. (2004). The plant samples were weighed as $10 \mathrm{~g}, 50 \mathrm{ml}$ of methanol was added to each of them and kept at room temperature overnight, and then extracted in an ultrasonic water bath for 1 hour. After centrifugation, the plant material was filtered with the help of filter paper and the plant sample was extracted twice more in the same way. After the extracts were collected and centrifuged at $3500 \mathrm{rpm}$ for 15 minutes, the solvent was removed in a vacuum rotary evaporator and a dry extract was obtained. The dried plant extract was stored at $-20 \mathrm{C}$ until analysis.

\section{Determination of Oil Content and Fatty Acid} Composition of Plant Extracts

Analysis of fatty acids of fixed oil obtained from seeds by the soxhlet method was performed by GC-MS according to Comlekcioglu (2019). GC-MS analyzes were performed with the Schimadzu GC 2025 system ${ }^{\circledR}$. A TRCN-100 $(60 \mathrm{~m}$ x $0.25 \mathrm{~mm} \times 0.20 \mu \mathrm{m}$ film thickness) SE-54 fused silica capillary column was used. The electron energy is $70 \mathrm{eV}$. The injection amount is $1 \mu \mathrm{l}$. After the samples were kept at $80^{\circ} \mathrm{C}$ for 2 minutes, the temperature was increased by $5^{\circ} \mathrm{C}$ per minute and kept at $140^{\circ} \mathrm{C}$ for 2 minutes. Following this process, it was kept at $240^{\circ} \mathrm{C}$ for 5 more minutes with an increase of $3^{\circ} \mathrm{C}$ per minute. The total analysis time was set as 61 minutes. The injections were carried out in split mode (1:50) at $240^{\circ} \mathrm{C}$ and the detector temperature was $250^{\circ} \mathrm{C}$. Helium is used as carrier gas and its flow rate is adjusted to $30 \mathrm{ml} / \mathrm{min}$. The gas flows used were determined as $\mathrm{H} 2=$ $40 \mathrm{ml} / \mathrm{min}$ and dry air $=400 \mathrm{ml} / \mathrm{min}$.

\section{Determination of Total Phenolic and Flavonoid} Contents and Antioxidant Activity

Determination of Total Phenolic Content

Total phenolic content of the samples was determined using the Folin-Ciaceltaeou Reactive (FCR) method which was modified from Obanda et al. (1997). Gallic acid (Sigma) was used as standard. The prepared solutions were read at $750 \mathrm{~nm}$ in a spectrophotometer (Perkin-Elmer Lambda EZ 150, USA). The absorbance values obtained were calculated in terms of mg gallic acid equivalent (GAE) / g dry sample weight with the help of the calibration curve created with gallic acid solutions.

Total Flavonoid Content Determination

Total flavonoid content in plant extracts was determined spectrophotometrically according to Chang et al. (2002). The standard solution was calculated with quercetin (Sigma) prepared at different concentrations $(25-200 \mu \mathrm{g} / \mathrm{mL})$. Absorbance was read in a spectrophotometer at $415 \mathrm{~nm}$. The absorbance values obtained were converted into $\mu \mathrm{g}$ quercetin equivalent / $\mathrm{g}$ dry sample weight.

\section{Antioxidant Activity Determination}

DPPH (1,1-Diphenyl-2-Picrylhydrazyl) Method

Antioxidant capacity (reduction capacity of free radicals) was defined by the DPPH method which was modified from Brand-Williams et al. (1995). Five different concentrations of solutions were prepared by diluting each 
plant extract. Ascorbic acid was used as the positive control. The results are shown as the IC50, which is the concentration required to reduce $50 \%$ of $\mathrm{DPPH}$ free radicals.

FRAP (Ferric Reducing Antioxidant Power) Method: The determination of iron ion reducing antioxidant power (FRAP) was done according to Benzie and Strain (1996). $50 \mu \mathrm{L}$ of plant extracts were transferred to $2 \mathrm{~mL}$ eppendorf tubes and $600 \mu \mathrm{l}$ of FRAP agent was added. Absorbance was measured at $593 \mathrm{~nm}$. Results were calculated as $\mu \mathrm{mol}$ ascorbic acid equivalent / g dry plant weight using ascorbic acid (100-1000 $\mu \mathrm{mol} / \mathrm{L})$ calibration graph.

\section{Results and Discussion}

\section{Fatty Acid Composition}

The oil contents of the plants were revealed as a result of GC-MS measurements, and the data of the fatty acid composition of the extract are given in Table 1 and GC-MS chromatogram in Figure 2. As a result of oil extraction, the oil amounts of plant extracts collected from Dulkadiroğlu / Aksu, Onikişubat / Ilıca and Göksun / Kanlıkavak locations were found to be $4.51 \%, 3.38$ and $4.15 \%$, respectively. According to the measurement results, a total of 26 different fatty acids were determined in $T$. terrestris extracts, 14 of which are saturated and 12 of which are unsaturated. Despite the diversity in saturated fatty acids, its ratio in all fatty acids was found to be low. Surprisingly, the majority of the oils from $T$. terrestris plant extracts (49.94-74.38\%) appear to consist of polyunsaturated fatty acids (PUFAs). According to the analysis, palmitic acid (7.96-12.22\%), oleic acid (13.28-28.99\%) and linoleic acid (48.38-71.00\%) constitute the main fatty acid components in $T$. terrestris extracts. In the samples examined, some compounds (caproic, caprylic, capric, cis-10heptadecanoic, arachidonic acids) were found only in plants collected from the Aksu location. It has been determined that some fatty acids (cis-5.8.11.14.17Eicosapentaenoic, Cis-8,11,14-Eicosatrienoic, Tricosanoic, Heptadecanoic, Lauric, Butyric acids) are absent at the Kanlıkavak location. Significant quantitative and qualitative changes were observed in some fatty acids ranging up to 1-2-fold concentration differences between locations. In the literature review, the scarcity of studies on the fatty acid composition of T. terrestris's fruit has drawn attention. Tian et al. (2019-B), obtained the main fatty acids in $T$. terrestris fruits as 7-octadecanoic acid, 9,12octadecadienoic acid. Javaid et al. (2019) obtained the main fatty acids in the body of the plant as oleic, palmitic, 6,9,12,15-docosatetraenoic acid, pentadecanoic acid, 9,12octadecadienoic acid, which is quite different from the results obtained in this study. It can be said that these differences in fatty acid ratios, both in other studies conducted in the world and in this study, are the responses given by plants to the combination of geographical or local ecological conditions.

While polyunsaturated fatty acids (PUFA) were found at the highest rate, monounsaturated fatty acids (MUFA) were identified at lower rates (Table 1). Palmitic (C16: 0), oleic (C18: 1) and linoleic acids (C18: 2n6) were found in extremely high ratios in their category (SFA-MUFAPUFA) as well as being the main fatty acids in the sample. Palmitic and oleic acids are the most abundant fatty acids in human tissues (Gunstone et al., 2007). These molecules exhibit health-promoting benefits in preventing cancer, causing a reduction in body fat, reducing obesity, antiinflammatory properties, and eliminating the severity of atherosclerosis and diabetes (Reiffel and Donald, 2006; Jabeur et al., 2017). Other PUFAs have been reported to exhibit physiological functions in promoting normal human metabolism, survival and death of heart cells, neuronal membrane development, and prevention of cancer (Pelliccia et al., 2013; Buckley et al., 2017). Linoleic acid is a polyunsaturated omega- 6 fatty acid and one of the two essential fatty acids that should be taken through the diet (Whitney and Rolfes, 2008). Therefore, a diet rich in foods containing omega 3-6-9 fatty acids is extremely important for our health. On the other hand, due to the higher content of mono and polyunsaturated fatty acids than saturated fatty acids, the fatty acid composition obtained from $T$. terrestris plant extracts is quite suitable for human nutrition.
The Average of Phenol Absorbance Values

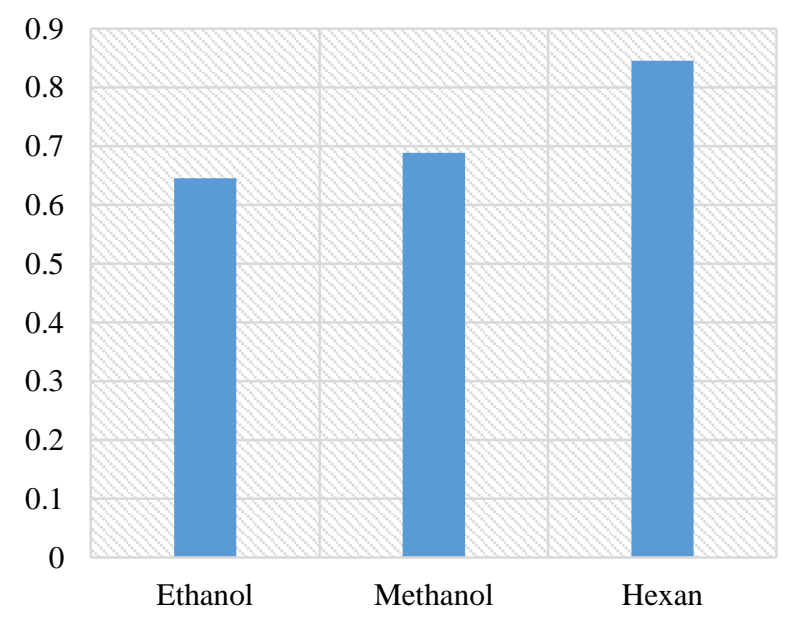

Crude Extract (\%)

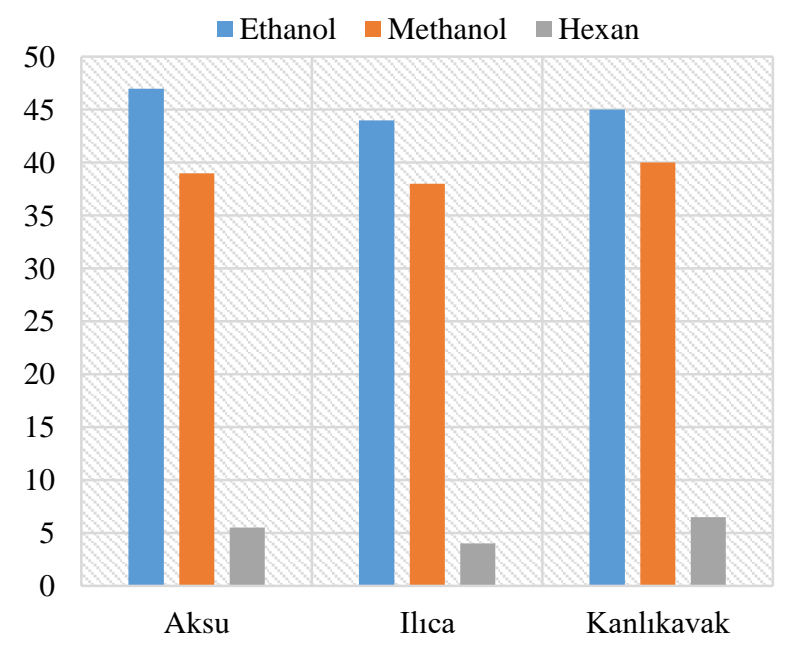

Figure 3. Absorbance values of the average of phenolic content and crude extract (\%) 
PHENOL

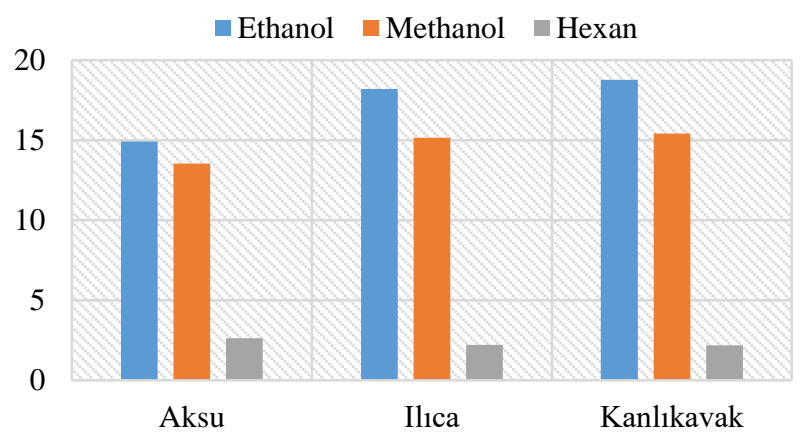

FRAP

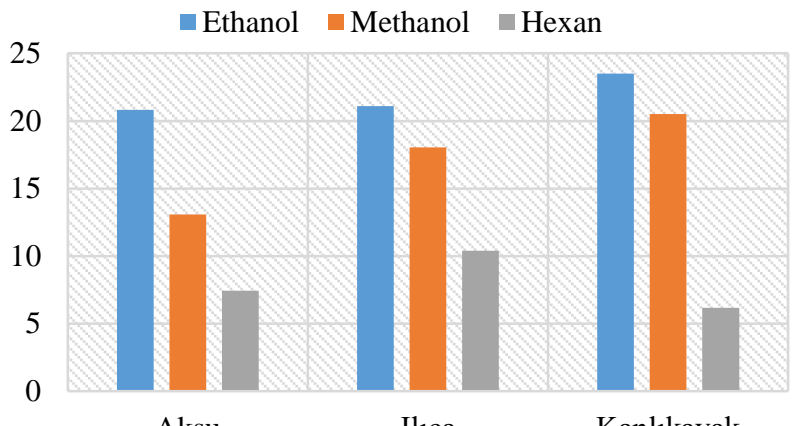

FLAVONOID

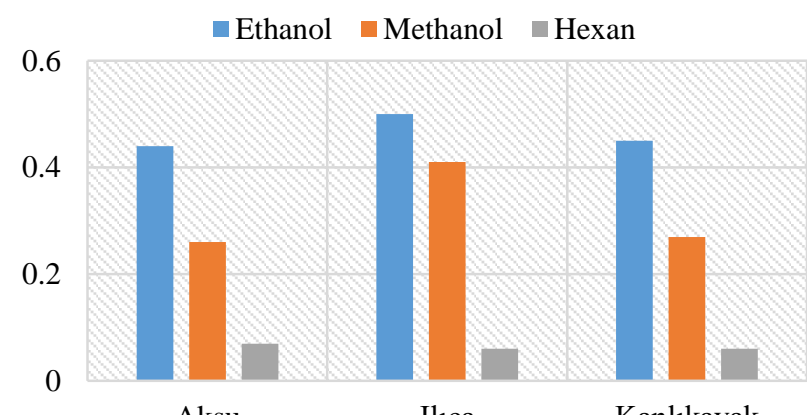

Aksu
Kanlıkavak
1/DPPH

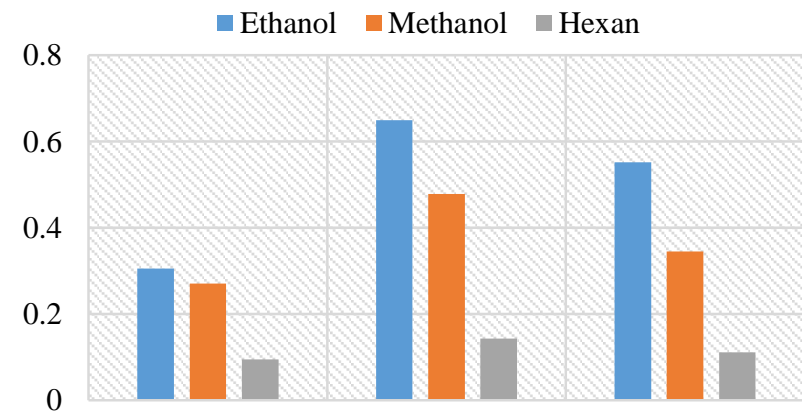

Aksu

Ilica

Kanlıkavak

Figure 4. Comparison of phenol, flavonoid, FRAP and 1/ DPPH in terms of location and solvents

Table 1. Fatty acid compositions of T. terrestris collected from different locations (\%)

\begin{tabular}{|c|c|c|c|c|}
\hline \multicolumn{5}{|c|}{ Lokasyon/Location } \\
\hline \multirow{2}{*}{$\begin{array}{l}\text { Carbon Numbers } \\
\mathrm{C} 4: 0\end{array}$} & Yağ asitleri Fatty Acids & \multicolumn{3}{|c|}{ Dulkadiroğlu/AksuOnikişubat/IlıcaGöksun/Kanlıkavak } \\
\hline & Butyric acid & $0.088 \pm 0.01$ & $0.224 \pm 0.01$ & - \\
\hline C6:0 & Caproic Acid & $0.068 \pm 0.02$ & - & - \\
\hline C8:0 & Caprylic Acid & $0.043 \pm 0.001$ & - & - \\
\hline C10:0 & Capric Acid & $0.113 \pm 0.02$ & - & - \\
\hline C12:0 & Lauric Acid & $0.223 \pm 0.01$ & $0.102 \pm 0.00$ & - \\
\hline C14:0 & Myristic Acid & $0.587 \pm 0.02$ & $0.512 \pm 0.03$ & $0.247 \pm 0.01$ \\
\hline $\mathrm{C} 15: 0$ & Pentadecanoic Acid & $0.032 \pm 0.01$ & - & $0.051 \pm 0.00$ \\
\hline C16:0 & Palmitic Acid & $12.22 \pm 0.21$ & $10.769 \pm 0.04$ & $7.959 \pm 0.11$ \\
\hline C17:0 & Heptadecanoic Acid & $0.056 \pm 0.00$ & $0.071 \pm 0.00$ & - \\
\hline C18:0 & Stearic Acid & $3.306 \pm 0.12$ & $4.909 \pm 0.02$ & $2.871 \pm 0.10$ \\
\hline C20:0 & Arachidic Acid & $0.17 \pm 0.03$ & $0.194 \pm 0.01$ & $0.091 \pm 0.00$ \\
\hline $\mathrm{C} 22: 0$ & Behenic Acid & $0.085 \pm 0.00$ & - & $0.337 \pm 0.00$ \\
\hline $\mathrm{C} 23: 0$ & Tricosanoic Acid & $0.262 \pm 0.01$ & $0.255 \pm 0.01$ & - \\
\hline $\mathrm{C} 24: 0$ & Lignoceric Acid & $0.174 \pm 0.01$ & $0,168 \pm 0.01$ & $0.272 \pm 0.01$ \\
\hline C14:1 & Myristoleic Acid & $0.086 \pm 0.01$ & $0.093 \pm 0.00$ & $0.043 \pm 0.02$ \\
\hline C16:1 & Palmiteloic Acid & $0.27 \pm 0.01$ & $0.431 \pm 0.01$ & $0.17 \pm 0.00$ \\
\hline C17:1 & Cis-10-Heptadecanoic Acid & $0.053 \pm 0.00$ & - & - \\
\hline C18:1 & Oleic Acid & $26.72 \pm 0.16$ & $28.988 \pm 0.10$ & $13.28 \pm 0.21$ \\
\hline $\mathrm{C} 24: 1$ & Nervonic Acid & $0.146 \pm 0.01$ & $3.346 \pm 0.03$ & $0.295 \pm 0.01$ \\
\hline C18:2 & Linoleic Acid & $51.50 \pm 0.11$ & $48.377 \pm 0.02$ & $71.00 \pm 0.23$ \\
\hline C18:3 & gama-Linolenic Acid & $0.22 \pm 0.01$ & $0.271 \pm 0.01$ & $0.338 \pm 0.12$ \\
\hline C18:3 & alfa-Linolenic Acid & $2.55 \pm 0.02$ & $0.69 \pm 0.01$ & $2.88 \pm 0.03$ \\
\hline C20:3 & Cis-8,11,14-Eicosatrienoic Acid & $0.32 \pm 0.01$ & $0.208 \pm 0.00$ & - \\
\hline C20:4 & Arachidonic Acid & $0.046 \pm 0.00$ & - & - \\
\hline C20:5 & cis-5.8.11.14.17-Eicosapentaenoic Acid & $0.399 \pm 0.03$ & $0.26 \pm 0.00$ & - \\
\hline $\mathrm{C} 22: 6$ & cis-4,7,10,13,16,19-Docosahexaenoic Acid & $0.253 \pm 0.01$ & $0.13 \pm 0.00$ & $0.162 \pm 0.02$ \\
\hline \multicolumn{2}{|c|}{ (SFA) Ratio of saturated fatty acid } & 17.427 & 17.204 & 11.828 \\
\hline \multicolumn{2}{|c|}{$\begin{array}{l}\text { (SFA) Ratio of saturated fatty acid } \\
\text { (MUFA) Ratio of monounsaturated fatty acid }\end{array}$} & 27.281 & 32.858 & 13.792 \\
\hline \multicolumn{2}{|c|}{ (PUFA) Ratio of polyunsaturated fatty acid } & 55.292 & 49.936 & 74.38 \\
\hline
\end{tabular}

Doymuş Yağ asidi Oranı (SFA), Tekli Doymamış Yağ Asidi Oranı (MUFA), Çoklu Doymamış Yağ Asidi Oranı (PUFA) 
Table 2. Total phenolic and flavonoid contents and antioxidant activity in T. terrestris extracts

\begin{tabular}{l|ccccc}
\hline Location & Solvent & $\begin{array}{c}\text { Fenol/Phenol } \\
\left(\mathrm{mg} \mathrm{GAE} \mathrm{g}^{-1}\right)\end{array}$ & $\begin{array}{c}\text { Flavonoid } \\
\left(\mathrm{mg} \mathrm{QE} \mathrm{g}^{-1}\right)\end{array}$ & $\begin{array}{c}\text { FRAP } \\
(\mu \mathrm{g} \mathrm{AAE} \mathrm{g})\end{array}$ & $\begin{array}{c}\text { IC50 değeri/IC50 Value } \\
(\% \mathrm{DPPH})\left(\mu \mathrm{g} \mathrm{mL} \mathrm{mL}^{-1}\right)\end{array}$ \\
\hline \multirow{3}{*}{ Aksu } & Ethanol & $14.93 \pm 0.25$ & $0.44 \pm 0.012$ & $20.83 \pm 0.69$ & $3.27 \pm 0.003$ \\
& Methanol & $13.55 \pm 0.21$ & $0.26 \pm 0.009$ & $13.09 \pm 0.25$ & $3.69 \pm 0.002$ \\
& Hexan & $2.65 \pm 0.05$ & $0.07 \pm 0.001$ & $7.42 \pm 0.13$ & $10.54 \pm 0.16$ \\
\hline \multirow{4}{*}{ Ilica } & Ethanol & $18.21 \pm 0.35$ & $0.50 \pm 0.000$ & $21.10 \pm 1.09$ & $1.54 \pm 0.021$ \\
& Methanol & $15.16 \pm 0.29$ & $0.41 \pm 0.005$ & $18.03 \pm 0.07$ & $2.09 \pm 0.024$ \\
& Hexan & $2.23 \pm 0.05$ & $0.06 \pm 0.002$ & $10.39 \pm 0.17$ & $6.97 \pm 0.13$ \\
\hline \multirow{3}{*}{ Kanlikavak } & Ethanol & $18.77 \pm 0.48$ & $0.45 \pm 0.016$ & $23.50 \pm 0.15$ & $1.81 \pm 0.005$ \\
& Methanol & $15.43 \pm 0.03$ & $0.27 \pm 0.013$ & $20.52 \pm 0.21$ & $2.9 \pm 0.04$ \\
& Hexan & $2.20 \pm 0.01$ & $0.06 \pm 0.003$ & $6.16 \pm 0.04$ & $8.94 \pm 0.27$ \\
\hline
\end{tabular}

\section{Antioxidant Activity}

In this study, total phenolic and flavonoid content of $T$. terrestris plant with Folin-Ciocâlteu and $\mathrm{AlCl} 3$ experiments and antioxidant activity with DPPH and FRAP tests were determined and the results are given in Table 2 . When the results are evaluated according to location, phenol and frap characters of Kanlıkavak; flavonoid and DPPH characters of Ilica has higher values than other locations. But the real change is seen in the solvent rather than the location. When evaluated according to the solvent, ethanol is superior in all the characters examined. According to the absorbance results in the experiments, a ranking was formed as hexane> methanol> ethanol. However, the reverse order (ethanol> methanol> hexane) was seen in the crude extracts (Figure 3). Since the crude extract values were included in the calculations, it was seen that the order of ethanol> methanol> hexane was valid (Figure 4). Phenolic compounds and flavonoids derived from plants have been shown to have abundant antioxidant activity in food products. Generally, extracts with high radical scavenging activity have high phenolic content. The differences observed in the composition may be due to many variables such as the solvent used to obtain the extract, soil quality, geographical and climatic differences and the harvest period (Stefanescu et al., 2020). In this study, locality and individual differences caused differences in the chemical contents of plants. However, the effect of the solvent used on the results reveals the importance of solvent selection in extraction.

When the literature data are examined, T. terrestris of Chinese, Indian and Bulgarian origin has been studied extensively. However, the phytochemical studies on $T$. terrestris located in Turkey, Russia, South Africa, Australia, Azerbaijan and Romania is inadequate (Hashim, 2014). T. terrestris is a plant known effects in Turkey and consumed among the people. Zheleva-Dimitrova et al. (2012) found the IC50 value as $2.84-4.56 \mathrm{mg} \mathrm{ml}^{-1}$ in $T$. terrestris herbal extracts and they stated the FRAP value as $2.29-3.33 \mathrm{mg}$. Tian et al. (2019-A) found the IC50 value of T. terrestris leaf extracts as $10.47 \mu \mathrm{g} \mathrm{mL}^{-1}$. These values are higher than the ethanol and methanol extracts obtained in this study. However, the lower the IC50 value in DPPH analysis, the better it is possible to remove free radicals and thus the free radical chain reaction can be disrupted (Lim et al., 2007). Therefore, extracts obtained from the plant using ethanol or methanol may be suitable for the pharmaceutical and food industries in the research of natural, environmental and healthy antioxidants and in the treatment of free radical pathologies, as they have higher antioxidant power.

\section{Conclusion}

In this study, phytochemical content analysis of $T$. terrestris, which was collected from different locations in the Kahramanmaraş region, was carried out considering the effective use of traditional medicine. The results showed the presence of different bioactive ingredients of $T$. terrestris in varying amounts according to locations. These compounds are known to be responsible for the antioxidant and antimicrobial capacity of plants. In this regard, the plant is a powerful natural source of antioxidants and may be useful in the treatment of free radical pathologies. Omega 3 fatty acids $\alpha$-Linolenic acid, eicosapentaenoic acid and docosahexaenoic acid; linoleic (major component) and gamma-linolenic acid of omega 6 fatty acids; It has an important profile as it contains omega 3-6-9 fatty acids, including oleic acid (major component), one of the omega 9 fatty acids. The data obtained in this study will help to understand the characteristics and advantages of this traditional herb used in folk medicine and will be applicable in the future to develop new products and herbal medicines.

\section{Acknowledgement}

We thank Abdulkadir Bilgin for his assistance in procuring T. terrestris.

\section{References}

Akram M, Asif HM, Akhtar N, Shah PA, Uzair M, Shaheen G, Shamim T, Shah SMA, Ahmad K. 2011. Tribulus terrestris Linn.: a review article. J Med Plants Res, 5(16): 3601-3605.

Amin AMR, Lotfy M, Shafiullah M, Adeghate E. 2006. The protective effect of Tribulus terrestris in diabetes. Ann N Y Acad Sci, 1084(1): 391-401.

Baytop T. 1999. Therapy with Plants in Turkey, Past and Present (second ed.), Nobel Tip Kitapevi, Istanbul.

Benzie IF, Strain JJ. 1996. The ferric reducing ability of plasma (FRAP) as a measure of "antioxidant power": the FRAP assay. Anal Biochem., 239(1): 70-76.

Brand-Williams W, Cuvelier ME, Berset CLWT. 1995. Use of a free radical method to evaluate antioxidant activity. LWTFood Sci Technol, 28(1): 25-30.

Buckley MT, Racimo F, Allentoft ME, Jensen MK, Jonsson A, Huang H, Hormozdiari F, Sikora M, Marnetto D, Eskin E, Jorgensen ME, Grarup N, Pedersen O, Hansen T, Kraft P, Willerslev E, Nielsen R. 2017. Selection in Europeans on fatty acid desaturases associated with dietary changes. Mol Biol Evol, 34(6): 1307-1318.

Chang CC, Yang MH, Wen HM, Chern JC. 2002. Estimation of total flavonoid content in propolis by two complementary colorimetric methods. J Food Drug Anal, 10(3): 178-182. 
Chhatre S, Nesari T, Somani G, Kanchan, D, Sathaye S. 2014. Phytopharmacological overview of Tribulus terrestris. Phcog Rev, 8:45-51.

Comlekcioglu N. 2019. Bioactive Compounds and Antioxidant Activity in Leaves of Endemic and Native Isatis spp in Turkey. Braz Arch Biol Technol, 62.

Cohen JE. 2001. World population in 2050: assessing the projections. In Conference Series-Federal Reserve Bank of Boston Vol. 46, pp. 83-113. Federal Reserve Bank of Boston; 1998.

Davis PH. 1969. Flora of Turkey and the East Aegean Islands. Vol. 3. Flora of Turkey and the East Aegean Islands. Vol. 2. pp 493.

Fusco D, Colloca G, Monaco MRL, Cesari M. 2007. Effects of antioxidant supplementation on the aging process. Clin Interv Aging, 2(3): 377 .

Gopinath V, MubarakAli D, Priyadarshini S, Priyadharsshini NM, Thajuddin N, Velusamy P. 2012. Biosynthesis of silver nanoparticles from Tribulus terrestris and its antimicrobial activity: a novel biological approach. Colloids Surf B: Biointerfaces, 96: 69-74.

Gunstone FD, Harwood JL, Dijkstra AJ. 2007. The Lipid Handbook, 3rd ed. Boca Raton: CRC Press.

Hammoda HM, Ghazy NM, Harraz FM, Radwan MM, ElSohly MA, Abdallah II. 2013. Chemical constituents from Tribulus terrestris and screening of their antioxidant activity. Phytochemistry, 92: 153-159.

Hashim S, Bakht T, Bahadar Marwat K, Jan A. 2014. Medicinal properties, phytochemistry and pharmacology of Tribulus terrestris L. (Zygophyllaceae). Pakistan J Bot, 46: 399-404.

Jabeur I, Pereira E, Barros L, Calhelha RC, Soković M, Oliveira MBP, Ferreira IC. 2017. Hibiscus sabdariffa L. as a source of nutrients, bioactive compounds and colouring agents. Food Res Int, 100: 717-723.

Javaid A, Anjum F, Akhtar N. 2019. Molecular Characterization of Pyricularia oryzae and its Management by Stem Extract of Tribulus terrestris. Int J Agric Biol, 21(6): 1256-1262.

Kim HJ, Kim JC, Min JS, Kim MJ, Kim JA, Kor MH, Ahn JK. 2011. Aqueous extract of Tribulus terrestris Linn induces cell growth arrest and apoptosis by down-regulating NF- $\kappa \mathrm{B}$ signaling in liver cancer cells. J Ethnopharmacol, 136(1): 197-203.

Lim YY, Lim TT, Tee JJ. 2007. Antioxidant properties of several tropical fruits: A comparative study. Food Chem, 103(3): 1003-1008.

Miliauskas G, Venskutonis PR, Van Beek TA. 2004. Screening of radical scavenging activity of some medicinal and aromatic plant extracts. Food Chem, 85(2): 231-237.

Mohammed MS, Alajmi MF, Alam P, Khalid HS, Mahmoud AM, Ahmed WJ. 2014. Chromatographic finger print analysis of anti-inflammatory active extract fractions of aerial parts of Tribulus terrestris by HPTLC technique. Asian Pac J Trop Biomed. 4(3): 203-208.

Mohammed FS, Akgul H, Sevindik M, Khaled BMT. 2018. Phenolic content and biological activities of Rhus coriaria var. zebaria. Fresenius Environmental Bulletin, 27(8): 56945702.

Mohammed FS, Günal S, Şabik AE, Akgül H, Sevindik M. 2020. Antioxidant and Antimicrobial activity of Scorzonera papposa collected from Iraq and Turkey. Kahramanmaraş Sütçü İmam Üniversitesi Tarım ve Doğa Dergisi, 23(5): 1114-1118.
Mohammed FS, Karakaş M, Akgül H, Sevindik M. 2019. Medicinal properties of Allium calocephalum collected from Gara Mountain (Iraq). Fresen Environ Bull, 28(10): 74197426.

Mohammed FS, Pehlivan M, Sevindik E, Akgul H, Sevindik M, Bozgeyik I, Yumrutas O. 2021. Pharmacological properties of edible Asparagus acutifolius and Asparagus officinalis collected from North Iraq and Turkey (Hatay). Acta Alimentaria, https://doi.org/10.1556/066.2020.00204

Noordin MA, Noor MM, Aizat WM. 2020. The Impact of Plant Bioactive Compounds on Aging and Fertility of Diverse Organisms: A Review. Mini Rev Med Chem, 20(13): 12871299.

Obanda M, Owuor PO, Taylor SJ. 1997. Flavanol composition and caffeine content of green leaf as quality potential indicators of Kenyan black teas. Journal of the Science of Food and Agriculture, 74(2): 209-215.

Pandey D, Gupta AK. 2020. Recent Advances in Medicinal Plant Secondary Metabolites as the Alternate Bioactive Therapy. for Better Human Health A Review. Secondary Metabolites of Medicinal Herbs.

Pelliccia F, Marazzi G, Greco C, Franzoni F, Speziale G, Gaudio C. 2013. Current evidence and future perspectives on n-3 PUFAs. International Journal of Cardiology, 170: S3-S7.

Reiffel JA, McDonald A. August 2006. "Antiarrhythmic effects of omega-3 fatty acids". Am J Cardiol, 98 (4A): 50i-60i.

Sevindik M, Akgul H, Pehlivan M, Selamoglu Z. 2017. Determination of therapeutic potential of Mentha longifolia ssp. longifolia. Fresen Environ Bull, 26(7): 4757-4763.

Sevindik M. 2020. Antioxidant and antimicrobial capacity of Lactifluus rugatus and its antiproliferative activity on A549 cells. Indian Journal of Traditional Knowledge (IJTK), 19(2): 423-427.

Sevindik M. 2021. Phenolic content, antioxidant and antimicrobial potential of Melanoleuca melaleuca edible mushroom. The Journal of Animal and Plant Sciences, 31(3): 824-830.

Ştefănescu R, Tero-Vescan A, Negroiu A, Aurică E, Vari CE. 2020. A Comprehensive Review of the Phytochemical, Pharmacological, and Toxicological Properties of Tribulus terrestris L. Biomolecules, 10(5): 752.

Tian C, Chang Y, Zhang Z, Wang H, Xiao S, Cui C, Liu M. 2019A. Extraction technology, component analysis, antioxidant, antibacterial, analgesic and anti-inflammatory activities of flavonoids fraction from Tribulus terrestris L. leaves. Heliyon, 5(8): e02234.

Tian C, Zhang Z, Wang H, Guo Y, Zhao J, Liu M. 2019-B. Extraction technology, component analysis, and in vitro antioxidant and antibacterial activities of total flavonoids and fatty acids from Tribulus terrestris L. fruits. Biomed Chromatogr, 33(4): e4474.

Whitney Ellie, Rolfes SR. 2008. Understanding Nutrition (11th ed.). California: Thomson Wadsworth. p. 154.

Wink M. 2015. Modes of action of herbal medicines and plant secondary metabolites. Medicines, 2(3): 251-286.

Zheleva-Dimitrova D, Obreshkova D, Nedialkov P. 2012. Antioxidant activity of Tribulus terrestris - a natural product in infertility therapy. Int J Pharm Pharm Sci, 4(4): 508-11. 